\title{
The Development of Religious Concepts among Muslim Student in Yogyakarta
}

\author{
Karlina Maizida \\ Yayasan Prasasti Perdamaian, Mataram \\ email:karlinamaizida@gmail.com
}

\begin{abstract}
This study aims to examine the religious development of Muslim children through their opinions about religion as well as their experience. It is intended to explore their understanding of some religious concepts and the factors influencing their understanding. The main participants of this study are six children in one of the religious private modernist schools in Yogyakarta from the first until the sixth grades (their ages are around 7-12 year old). The researcher expects that the children religious concept develops in accordance with the cognitive development theory. Moreover, since all participants are Muslim, it is expected that there is a different nuance from the previous research which particularly discusses the concept of God. If social environment takes an account of children religious concept, the researcher expects to find out which aspect is more dominant: the aspect of family or the aspect of the school. The results showed that the children's religious concept grows as something inseparable from the rest of the children's development, from concrete to more abstract knowledge, from simple to more complicated view. The social environment, particularly religious instruction at school, plays a central role in the children's religious concept.
\end{abstract}

\section{Keywords:}

Children, Religious concept, Cognitive development, Islamic school 


\section{Introduction}

Piaget's cognitive development theories suggest that children do not have abstract thinking until they reach the age of 12 year old (Piaget 1954). Religion is merely a fully imitative and naive practice for children. Thus, they just take the doctrine uncritically. However, children are usually involved with religion. Some activities, such as: Sunday school, religious instructional class, memorizing the Koran in mosque every afternoon, and so forth are conducted to make children become religious human beings. It has been a common assumption that parents are the most influential party in children development. Nevertheless, we cannot deny the role of teachers, environment, or even the child itself in the children's religious development. Children learn about religion either directly or indirectly from adult or more experienced peers (Nazar F. 2003; Trovao 2017; Ter Avest et al. 2017; Allana et al. 2017). In Religiosity in Diversity: Aku Anak Sholeh, a short documentary film published by CRCS in 2006 there is a scene when a seven year old boy says:

"All religions are true; God had blessed us with a religion since we were born. Catholics can go to heaven as well as Muslim people. Sinful Catholic would go to heaven as well as sinful Muslim".

In a subsequent scene, another boy says, "Infidels are evils, infidels are not Muslim. They are wicked and impenitent to their parents". The statement of some children above shows that children achieve some religious concepts from diverse perspectives. It means that children are not just adult miniature, as stated by Spilka (2003). They live in their own world and have their own cognitive character.

Hyde shows that the study of religion in childhood and adolescence has been dominated for thirty years by the explorations of the development of religious thinking influenced by the writing of Piaget on cognitive development theory (Hyde 1990). He believes that the way children think about their world progresses systematically as they grow up from sensory 
motor, as the first stage, to formal operation, as the last and complete stage (Piaget 1954; Inhelder and Piaget 1964). Moreover, Nye puts on conclusion that the development of religious conceptualization tends to lend credence to Piaget's cognitive development theory (Nye 1981).

Some scholars have done research in order to examine specifically some religious concepts, such as the concept of God (Harms 1944), prayer (Long, Elkind \& Spilka 1967) and faith (Fowler 1981), as well as religious development (Alport 1953; Thun 1959; Goldman 1964; Elkind 1964, 1970). They report that the characteristic of the child's religious concepts is their anthropomorphism and egocentrism. Children tend to view God as an old male personage or as a superpower. Furthermore, he explains that parents are figures that influence children's thinking and acceptance of religious practice. Both Goldman and Elkind apply Piaget's theory and conclude that religious thinking does indeed proceed in a fashion similar to more general development (Spilka 2003). Then, in 1959, there was an investigation on three different groups to report their religious thoughts and experience through questions on several themes, such as Christ, heaven and hell, prayer and death (Wulff 1997).

\section{Method}

The participants of this study are six children between 7-12 year old in one of religious modernist private schools in Yogyakarta. This is a qualitative study and the researcher uses phenomenological approach. The development method in this research is cross-sectional approach. Using the theory and operational construct method based on certain purpuse, it is found out that the participats are the primary data. The researcher was the participant observer in classrooms during the religion lesson. Other than observation, the researcher selected the participants based on the portfolio of such family background, biography and academic report. In accordance with the principle of qualitative method, which emphasized 
on uniqueness, the researcher tried to find informants from various backgrounds.

During January and May 2010, the researcher went to the school every day to conduct interview and observation. The in depth and semistructured interviews were conducted every morning with different child for approximately 20 to 30 minutes per session. The interviews raised several questions of some themes, such as the meaning of religion, concept of God, Islamic faith (iman) and Islam, heaven and hell, sin and grace, angels and devil, the prophet, the experience of life and death, the universe and existence of other faiths and the practice of worship and prayer, destiny and the end of the world. The number of the questions are flexible. Indeed, the researcher explored information by digging and doing probing actively than following the interview guideline strictly. Besedes, the researcher also observed the informants' daily behavior at the school. As the secondary data, the researcher also interviewed religious teacher to explore about religious education, which is given at the school, as well as the school principal to apprehend the school programs and the curriculum. The table below shows the demographic information of the informants.

Table (1)

The Backgrounds of the Informants

\begin{tabular}{|c|c|c|c|c|c|c|c|}
\hline No & Name & Sex & Birth & Age & Class & $\begin{array}{l}\text { Score of religious } \\
\text { lesson in } 1^{\text {st }} \mathrm{Smt} / \\
\text { Class Rank }\end{array}$ & Parent's occupation \\
\hline 1 & Nurul & Girl & 19 March 2003 & 7 & $\mathrm{I}$ & $89.75 / 8$ & $\begin{array}{l}\text { Father: meatball seller } \\
\text { Mother: - }\end{array}$ \\
\hline 2 & Dito & Boy & $\begin{array}{c}24 \text { February } \\
2002\end{array}$ & 8 & II & $91.75 / 2$ & $\begin{array}{l}\text { Father: private sector } \\
\text { employee } \\
\text { Mother: - }\end{array}$ \\
\hline 3 & Ani & Girl & 10 March 2001 & 9 & III & $82.5 / 39$ & $\begin{array}{l}\text { Father: civil servant } \\
\text { Mother: civil servant }\end{array}$ \\
\hline 4 & Jaka & Boy & 29 March 1999 & 11 & IV & $90 / 1$ & $\begin{array}{l}\text { Father: trader } \\
\text { Mother: teacher }\end{array}$ \\
\hline 5 & Ryo & Boy & $\begin{array}{c}27 \text { December } \\
1999\end{array}$ & 10 & $\mathrm{~V}$ & $85 / 21$ & $\begin{array}{l}\text { Father: printing company } \\
\text { employee } \\
\text { Mother: seasonal trader }\end{array}$ \\
\hline 6 & Naswa & Girl & 6 June 1997 & 12 & VI & $94 / 3$ & $\begin{array}{l}\text { Father: construction labor } \\
\text { Mother: - }\end{array}$ \\
\hline
\end{tabular}

Note: All names used here are pseudonym 


\section{The Concept of Religion, Islamic Faith, God, and Other Believers}

Most of the studies and research projects propose eleven different religious concepts to the informants as mentioned before. This article only focuses on explaining four of them, including how the children consider the meaning of religion, Islamic faith, the concept of God and the existence of other faiths or believers.

\section{Religion}

The informants show various responses regarding the questions raised by the researcher. Two informants (Nurul and Ani) argued religion is something that people had. They did not explain further about the meaning of 'something'. Two other informants stated that religion is human's belief and faith to the Deity (Dito and Naswa). Two last informants gave different answers. A unique answer is from an 11 year old boy who said, "Religion is an organization led by God" (Interview Jaka). He did not explain more about the meaning of an organization. When a follow up question about whether God has a religion or not was asked, he said that God has no religion. Thus, according to Jaka's answer, it seems that he has inconsistent way of thinking.

All children belief that God has created religion but two informants divided the origin of religion onto different sources. They separated between Islam and other religions. "Islam was created by God but other religions were created by humans" (Interview Ani, 9). Another student said, "Islam came from Allah and delivered by the prophets. Other religions were made by men, for example Christianity" (Interview Ryo, 10).

Five informants argued that only humans who have religions because as God's creatures, humans are completed with reason and mind. One respondent (Interview Ani, 7) said that animals also have religions but, on the other hand, not all humans have religion. Informants also 
agree that as the creator, God doesn't have any religion. Nevertheless, one boy (Interview, Ryo 10) stated that God has a religion and His religion is Islam. Here, we can see Ryo's possessiveness on Islam as his identity. He thought there is a relation between the only one God (Allah) and Islam, or, in other word, only Muslim who have God.

Children at the age of 7 to 9 tend to consider that religion is ordained strictly by God. God gives religion to humans and it is impossible for someone to convert (especially for Muslim). This finding supports the conclusion of Elkind $(1970,35-42)$ that 5 to 7 year old children seem to think that their affiliation to religion are absolute and has been ordained by God. Thus, as cited from Wulff $(1997,565-567)$, the first characteristic of children's religion is readiness for religion. Indeed, their response to religious doctrine is uncritical and spontaneous, without special prompting. In this study, I find a unique answer from 9 year old girl about conversion.

"Yes, it can. However, if they are Islam, they cannot convert (to other religions). People convert because they want it and because the number of the adherents of some religions is still few. For example, Catholics convert to Hindu because the number of Hindus is still few so they (Catholics) convert to Hindu". (Interview Ani, 9)

Children at the age of 10 to 12 begin to realize that human affiliation to religion could be a personal choice. There is a possibility to convert from one religion to another due to some personal reasons, such as the willingness, and the doubtness as well as the weak commitment towards their previous faith. In point of fact, this stage is one step ahead from the religious development studied by Elkind even though the children's reasons seem illogical (Elkind 1970, 35-42).

\section{Islamic Faith}

The researcher also explores the more specific aspect, the concept of Islam as the religion of all informants. Izutsu highlights that the concept 
of belief (iman) in Islam is crucial. It is as a character of the existence of Islam as the religion (Izutsu 2006). Therefore, this researcher also asked questions about Islam and iman to the informants.

All informants stated confidently that their religion is Islam. Parents played a very central role in determining their identity as Muslims. Family is considered as the first party from which they recognize Islam, as student said "I know that I am Muslim through my parents." (Interview Nurul, 7), "My mom and dad told me that I am Muslim" (Interview Jaka, 11), "My parents are Muslims, that's why I am following them and because they are Muslim it is impossible for me to be others" (Interview Ryo, 10). Parents have introduced Islam to these children through reading and memorizing The Koran. They usually send their children to TPA (Taman Pendidikan AlQuran) in the afternoon at a mosque or musholla (small mosque).

The meaning of Islam for them is various. Nurul (7) was silent when the researcher asked about the meaning of Islam. She only said that she knew Islam from her parents. Other informants argued that Islam is a belief to one God. Children tend to belief that Islam is the best and noble religion, "Islam is Muslims' belief, it means savior, savior from everything” (Interview Dito, 8). Another student said, "Islam is Muslims' religion which is created by God; Islam comes from God and it is the best religion" (Interview Ani, 9), "Islam gives the right guidance such as mutual assistance and fraternity" (Interview Ryo, 10).

Iman, for these children, means a belief or a faith to Allah and to all His commands, such as five daily prayers (shalat), fasting, and hajj. Iman for children at the age of 7 to 9 means only a practice; as Dito, 8, said "Iman is a belief to do shalat"; whereas for 10 to 11 year old children, iman means a belief to one God (Allah), "Iman is a belief to Allah and to five pillars of Islam" (Interview Jaka, 11). Lastly, for 12 year old child iman means both belief and practice,'Iman is the surrender of the heart, mouth and body" (Interview Naswa, 12). When the question about who the believers 
are was asked, all informants stated that believers are people who worship God. Furthermore, they mentioned that people who does not worship Allah, means that they are unbelievers; such as kafir and people who are not Moslem. God will send them to hell and they will remain in an eternal flame. The results also shows that iman for children at the age of 7 to 9 year old means only practice whereas for children from 10 to 11 year old means belief to one God (Allah) and for 12 year old child means both belief and practice. This results support Elkind's study about the changing of religious identity significance (Elkind 1970, 35-40).

\section{The Concept of God}

Although there are various religious concepts, the idea about God always becomes the first and the most widely investigated. Research related to the concept of God in childhood have a long history (Hyde 1990) and mostly based on Christianity (Nyhof and Johnson 2017, 60-75). Piaget, as cited in Nyhof (2017 60-75) states that the development of the concept of God has been considered through a concrete, embodied agent to an abstract idea. The summary of the research of the concept of God in children usually leads to the report that God is an anthropomorphic. Based on the interview session, it is found out that there are some differences about how children portray God compare to the previous research. All of the informants address God as Allah. In this study, God is still seen from the perspective of anthropomorphic. It does not discuss the physical forms of God but rather on God's invisible characteristics. God is seen as an old man with white-face like kyai (Islamic priest) and has no lust by 10 years old boy. In the first interview, the youngest child portrayed God as a man but when the third interview was held, she immediately changed her answer by saying:

"God does not look like human, has no gender, no children and wife, never sleep, God does not like anything else. God is good and merciful. God is in the distant sky, far away". (Interview Nurul, 7) 
Here are some verbal responses from the children about the concept of God:

"God has heaven, has the strength that can repay the evil man. Allah is good and commendable. Allah is in the sky and Allah sees human beings with different eyes which humans have". (Interview Dito, 8)

"I don't know, I cannot draw Allah because it is forbidden, it is a sin. Allah is the one who created nature and men. How many God do we have? God does exist but actually everyone does not believe yet because no one has ever seen God. God asks humans to worship Him". (Interview Ani, 9)

"Allah is great, ehmm...I don't know. According to Asmaul Husna, Allah is great, merciful, omniscient and the only one. I don't know where God is, He can exist everywhere because God is not restricted by any space". (Interview Jaka, 11)

"Allah is holy and cannot be described. It's like a soul, soul that we do not know where and what it looks like but we believe that it exists. Allah is in arsy, it is His throne and He may oversee human". (Interview Naswa, 12)

In this study, God is seen from anthropomorphic perspective. God is seen from His invisible characteristics, such as all-knowing, merciful, the greatest, and so on. All informants think that God is not a human being even though some of them address several characteristics of human to God in more extraordinary terms. These children realize that God has different mental power from human such as all-seeing, omniscience and has power to do anything. It seems that they can differentiate God's mind and human's mind, as stated by Heiphetz (2016) “from Piaget's account predict by the time children have reached early elementary school years, they will be able to differentiate God's mind from human minds".

Nevertheless, in this study, the development of children's God concept which is similar with Piaget's cognitive development confirmed by the previous research seems blurry. The results show that 10 year 
old child has a concrete anthropomorphic perspective on the image of God. Ryo (10) is the only child in this study who views God as an old man. Nevertheless, he realizes that God has different mental power from human.

This study indicates that some abstract properties and characteristics of God may actually be really understood by children. Even though God is seen from the perspective of anthropomorphic, God still has special mental power and abilities. This finding supports the research conducted by Nyhof (Nyhof and Johnson 2017, 60-75). Children in this study know God as a supernatural agent which is different from human. Moreover, all participants give supernatural attribution to God, such as omniscient, omnipresent, all-seeing, merciful, powerful and commendable.

An abstract portray of God is owned by children above 11 year old. These ages are earlier from Piaget's cognitive stage development which puts 12 year old and above, children at the stage of formal operational. At the formal operational stage, children start to have abstract view of the world. From the result, we can see that gender differences also influence their concepts of God. Boys conceptualize God on male characteristics, such as great, big, strong and powerful; while girls put on female characteristics, such as creator, kindness, loving and caring.

\section{The Existence of other Religions}

All my participants know that Islam is not the only one religion in the world. They realize that there are some other religions, such as Catholic, Christianity, Hinduism, Buddhism and Confucianism. They did not mention Judaism, Sikhism, and Taoism and so forth because in Indonesia people only recognize six official religions. These children also make friends with those from other faiths. These children showed various expression when they were asked about the actions conducted by people from different religions. All participants mentioned people of other faith's 
activities, daily behaviors, and their belongings. They made clear separation between Muslim and non-Muslim, such as the ritual and practice. "They have a dog, uh... It's horrible! But I know his name is Kiko (smiling). I don't know, my teacher had not yet told me about that" (Interview Nurul, 7). Another informant said, "Yeah, they do not perform shalat, they have God but I don't know how their God looks like" (Interview Dito, 8). Meanwhile, Ani (9) said, "They do not perform shalat, they have different kinds of ritual; they worship to different God; they worship to statues and Jesus". Another informant, Ryo (10), said, "At the time when somebody dies, we, as Muslim, will read surah Yasin but Christian, will sing songs and play guitar; they have a Deity but actually He is man; Jesus Christ is a human created by God".

Whatever their concern about people of other faiths, it did not affect the way these children make friendship with friends from other religions. They usually play together and help each other.

This study shows that the participants' knowledge and view about other religions and believers have been influenced by their religious education at school. Nevertheless, all participants have good friendship with their peers from different religions. This result supports the research conducted by Listia et.all (2007). On the other hand, one of the finding show that, generally, elementary school students do not put any account on a religion to choose their playmates. Children has an egocentric perspective, as stated by Thun in (Wulff 1997) and (Elkind 1970). Therefore, their connection to social environment is based on mutualism as something reciprocal.

\section{Children Conceptualization of Religion}

All participants have positive attitudes towards religion. They use many religious words but do not give clear explanation, at least until they reach 9 year old. Nevertheless, they have inconsistent way of thinking as stated by Goldman who reports that children's ideas about religion 
are drastically misunderstood because their reasons are far from logic (Goldman 1965). Sometimes, they were trapped in their own statements without having adequate capabilities in relating the ideas. A clear understanding and explanation was deliverd by one of the participants, Najwa (12). It may because her abstract thinking begins to develop (Piaget in Ginsburg and Opper 1964). Nevertheless, her argument is still in a very realistic way.

From the interview about the meaning of religion, Islam and faith, we can say that children's opinions about religion are quiet literal. Their concepts are very realistic. Their explaination about some religious concepts are somehow, more or less, similar to those written in the religious textbooks or taught by the teachers of religious education (Sai 2017). It means, as stated by Hyde that children interpreted what they heard in terms of what they knew (Hyde 1990).

The interesting result of this study is how children conceptualize God. The image of God in their mind is more abstract compare to the previous research showing that most children's perception of God is like a king, an old man, or a hero (Spilka 2003). It might be because Muslim children do not have real reference and image of God, just like Jesus in Christian. Nyhof shows that Muslim students are frequently attributed supernatural mental abilities to God than Catholic children (Nyhof and Johnson 2017). The concept of God moves from concrete to more abstract idea which is in line with the cognitive development as shown by Goldman (Goldman 1965). Based on the findings, a 10 year old child said that God is like humans, while the children at younger ages did not reflect the same idea or, at least, they did not express their ideas explicitly.

Another interesting finding of this study is that teacher and religious education give more influence to the participants' understanding about religious concepts rather than parents. During the interview sessions, all informants said "my teacher said" or "it never been told in class" more 
often. This finding is different with Hyde (1990) who says that, in terms of fostering religiousness to children, parental influence is associated more strongly than school. Hyde's statement might be true if we consider the decision of the parents to send their children to private religious school than state school. Parents also play a very central role in giving the basic information about religion (Islam) as children's identity. However, when children grow up with broader knowledge and understanding about religion, they would gain more influences from the school and teachers, especially when the parents does not give much supports and attentions in their children's academic progress. The school where the research was conducted has unique characteristics. The majority of the students in this school are from lower class families. Based on my interview with the principal and the teachers, they reported that the parents tend to hand over the educational affairs to the school. Therefore, it is possible that the school and the teachers have stronger influence on the children's religious development rather than parents.

Religion for children means practices rather than a belief. It is clearly shown when the children discussed about iman (faith). They distinguished between believer and unbeliever by giving clear explaination about the behaviors and religious practices. It is unsurprising because the school emphasizes more on the religious practices. Their possessiveness on the religious practice and worship seems more obvious when they talked about the existence of other religions. They clearly distinguished between Islam and other faiths based on symbols, daily behaviors, religious practices and ownerships. Their opinions about the differences between Islam and other religions in Indonesia are developed into some judgments, which are visibly lead to exclusivism. This is the product of religious education, in specific, and system of education, in general. In this study, we can also address that religious instruction at school has cumulative effect at older ages. 
The enforcement of religious education at school becomes debatable both in terms of its content and importance, especially in public school. Goldman says that an adult do not expect a week old baby to walk (Goldman 1965). Unfortunately, we give children fully abstract religious concepts through religious education and instruction at school when; on the other hand, the children are still in the stage of having concrete understanding about the world (Brown 2017; Byng 2017; Kosher 2017; Kvarfordt 2017). Religious growth is inseparable from the rest of a child's development. They have limitation on cognitive as well as linguistic maturity so it will be better if the adults give them chances to explore their environment in order to enrich their experience about the world. In praxis, religious education, which is given at this school -the school where the research was conducted is less concerned on how to live in multicultural condition (just like in Indonesia). Furthermore, it lacks of tolerance feeling to other faiths. Actually, it happens not only at this school but also at most of the schools in Indonesia and even in America. Saphiro argues that students lose their hearts, spiritualties and moral conducts in interaction among people across cultures because the teacher and curriculum only emphasizes more on the numerical value (Shapiro 2006). Moreover, Starrett notes that a school is only a place designed to equip student with sufficient knowledge to keep the interest of the state (Starrett 1998). Based on the interview with the teacher, actually, they realize that the curriculum, which is designed by the government, is difficult for students because it contains too many materials and only emphasizes on instant result. Nevertheless, they cannot refuse the curriculum.

Even though this research does not explore the broader practices and implications of religious education to children, it is reasonable to consider the argument of Starret, "the amount of religion to which students are exposed at school depends on the nature of the school and the personality of teacher who can encourage or discourage religious expression on the part of pupils." (Starrett 1998, 122; Brown et al. 2017; Ohlendorf, Koenig \& Diehl 2017) 
The school where the research was conducted is one of religious private schools in Yogyakarta. Religious instructions at this school are given intensively within eight hours per week. Instead, state and other public schools only has two hours per week. The number of hours of religious instruction that does not include other religious activities is already scheduled. Some pictures below show the daily activities at the school.

Based on the interview session, the religious teachers of the lower grades (from the first to third grades) argued that the concept of iman (Islamic faith) and aqidah (belief to one God) are the most important thing that should be given to the students of early ages. Meanwhile, the teachers of the upper grades argued that akblaq (moral conducts) is the most important thing to be given to students. All religious education teachers at this school agree that it is very important to give religious education to students. Indeed, the school emphasizes more on the religious rituals and practices. This finding supports Starrett's argument above.

\section{Conclusion}

Children at the ages of seven to twelve have different ideas about some religious concepts depending on the religious instruction, family, sex, and age. Parents may give children basic information about religion. Nevertheless, children gain broader knowledge and understanding about religion from the school and teachers. The aspects of teachers and religious instruction at school seem to be more dominating for the development of children's religious thinking than the aspect of parents. Nevertheless, parents who put more attentions and supports in the development of the children's education make the children more proficient in developing their abstract thinking. The influence of gender differences appear when the children show their opinion about God. Age also influences the development of their religious thinking. However, the discussion of age difference is a little bit delicate. 
The explanations of religion from a 7 year old child reflect her understanding that religion has been ordained strictly by God. She uncritically accepts every religious concept written in her book. Many of her ideas are misunderstood, not logical and not based on clear explanation and understanding. Other children, show that they are aware of their identity as Muslim although the identity is based more on the practices rather than beliefs. Over time, these immaturities would gradually disappear as children reach the age of twelve when the capability of the abstract thinking begins to develop.

As the reflection of the research, I gave the last question to them whether they have question regarding to religion, which is unanswered until now. Children who are seven and eight year said that they do not have any question. They do not really care about it and religion seems does not mean anything to them. Question about the existence of God, what $\mathrm{He}$ is and where He is come from meet the mind of children who are nine to eleven year old. While, twelve-year-old child asked about the existence of deviant cult. At the end, when the study shows that religious instruction at school give significance influence to children religious concept it would be important to taught children about living inclusively. To this point, I cited from Nazar that "children should be taught to developed tolerance for religion based differences and should be provided with tools to think and learn religion in variety ways".(Nazar F. 2003). 


\section{References}

Allana, A.R., Tennant, G., Petrucka, P. 2017. International Journal of Children's Spirituality 22 (3-4), pp. 239-259.

Brown, C. S., H. Ali, E. A. Stone \& J. A. Jewell (2017) U.S. Children's Stereotypes and Prejudicial Attitudes toward Arab Muslims. Analyses of Social Issues and Public Policy, 17, 60-83.

Byng, M. (2017) Transnationalism among second-generation muslim americans: Being and belonging in their transnational social field. Social Sciences, 6.

Elkind, David. 1970. "Age Changes in the Meaning of Religious Identity." Review of Religious Research 12: 36-40.

Ginsburg, Herbert P, and Sylvia . Brandt,Opper. 1964. Piaget's Theory of Intellectual Development. Englewood Cliffs: Prentice Hall.

Goldman, Ronald J. 1965. Readiness for Religion. London.

Hyde, Kenneth E. 1990. Religion in Childhood and Adolescence : A Comprehensive Review of the Research. Birmingham, Ala.: Religious Education Press.

Inhelder, Barbel., and Jean Piaget. 1964. Early Growth of Logic in the Child; Classification and Seriation, Aby Barbel Inhelder and Jean Piaget. New York: Routledge and Paul.

Izutsu, Toshihiko. 2006. The Concept of Belief in Islamic Theology. Kuala Lumpur: Islamic Book Trust.

Kosher, H. \& A. Ben-Arieh (2017) Religion and subjective well-being among children: A comparison of six religion groups. Children and Youth Services Review, 80, 63-77.

Kvarfordt, C. L. \& K. Herba (2017) Religion and Spirituality in Social Work Practice with Children and Adolescents: A Survey of Canadian Practitioners. Child and Adolescent Social Work Journal, 1-15.

Nazar, F., \& Kouzekanani. 2003. "A Cross-Cultural Study of Children's Perceptions of Selected Religious Concepts Kuwait, the United States, and India]." Alberta Journal of Educational Research 49 (2). https:// search-proquest-com.ezproxy-alumni.lib.monash.edu.au/ docview $/ 228634708$ ? accountid $=12528$.

Nye, W Chad. 1981. The Development of the Concept of God in Children.

Nyhof, Melanie A, and Carl N Johnson. 2017. "Is God Just a Big Person? 
Children's Conceptions of God across Cultures and Religious Traditions." BJDP British Journal of Developmental Psychology 35 (1): $60-75$.

Ohlendorf, D., M. Koenig \& C. Diehl (2017) Religion and Ethnic Educational Inequalities - Theoretical Arguments, Empirical Findings and Open Questions. Kolner Zeitschrift fur Soziologie und Sozialpsychologie, 69, 561-591.

Piaget, Jean. 1954. Construction of Reality in the Child. Londo: Routledge. Sai, Y. 2017. An Exploration of Ethos in Irish Muslim Schools: Ethnographic Insight and Perspectives from Parents and Teachers. Journal of Beliefs and Values, pp.1-16.

Shapiro. 2006. Loosing Heart: The Moral and Spiritual Miseducation of America's Children. New Jersey, USA: Lawrence Erlbaum Associates Inc.

Spilka, Bernard. 2003. "The Psychology of Religion: An Empirical Approach.” Princeton, N.J.: Recording for the Blind \& Dyslexic.

Starrett, Gregory. 1998. Putting Islam to Work : Education, Politics, and Religious Transformation in Egypt. Berkeley: University of California Press.

Ter Avest, K.H., Rietveld-van Wingerden, M. 2017. Half a Century of Islamic Education in Dutch School. British Journal of Religious Education 39 (3), pp. 293-302.

Trovao, S.S. 2017. Parental Transmission of Religion and Citizenship among Migrant Muslim Families in Mozambique, Portugal, United Kingdom and Angola. Journal of Muslim Minority Affairs 37 (2), pp. 129-146.

Wulff, David M. 1997. Psychology of Religion: Classic and Contemporary Views. New York; Chichester: J. Wiley. 